\title{
Habitat Effect on the Essential Oils, Phenolics and Flavonoids of the Medicinal Weed Apium graveolens L.
}

\author{
M.S.Serag ${ }^{a^{*}}$, S.R.Gedara ${ }^{\mathrm{b}}$, A.Z. Abo El- Naga ${ }^{\mathrm{a}}$, N.G. Amer ${ }^{\mathrm{a}}$ \\ ${ }^{a}$ Botany Department, Faculty of Science, Damietta University, Egypt \\ ${ }^{\mathrm{b}}$ Pharmacognoncy Department, Faculty of Pharmacy, Mansoura University, Egypt
}

Received: 31 March 2013 / Accepted: 02 May 2013

*Corresponding author (Tel: +20. 01003489609, email: mamdouhserag054@ gmail.com)

\begin{abstract}
The present study aims to determine the relationship between soil chemical characteristics and the yield, qualitative and quantitative composition of the essential oils, as well as, phenolic and flavonoid content of the Apium graveolens L. (Apiaceae) aerial parts and fruits. Field study indicated that Apium graveolens L. is widely distributed in the Nile Delta coast namely, sandy fertile cultivated lands, banks of irrigation canals, Orchards, reclaimed lands and waste land. Soil analysis indicated that $A$. graveolens L. grow in a wide range of soil variables such as conductivity, calcium carbonates, organic carbon, chlorides and potassium, sodium, calcium and magnesium cations. The volatile constituents were analyzed by GC/MS. The detected compounds were identified by their retention times and mass spectral data, as well as comparison with published data or with reference compounds and mass spectrometric libraries of REPLIB and MAINLIB. Significant differences in the proportion of volatile constituents from oils of different habitat were detected. Besides, the phenolic and flavonoid content of the aerial parts and fruits varied widely according to habitat type. Hence, great attention must be paid to the type of soil and cropping strategies, to obtain satisfactory yields of high quality products, respecting their safety and medicinal value.
\end{abstract}

Keywords: Apiaceae, Apium graveolens L., GC-MS, phenolic compounds, soil variables, volatile oils

\section{Introduction}

Apiaceae (Umbelliferae) is a unique family in the flowering plants due to the characteristic inflorescences and fruits, besides the distinctive chemistry reflected in odour, flavour and even toxicity of many of its members. Several umbellifers plants were known to ancient Chinese and Mexican Indian civilization, as well as, to the Egyptians, Greeks and Romans of the Mediterranean basin [1].

Apiaceae is a cosmopolitan family comprising 446 genera and over 3540 species which makes this family one of the largest taxon among higher plants [2]. Plants of family Apiaceae are usually used medicinally as a cure for gastrointestinal complaints and cardiovascular ailments. They are also used as antispasmodics, sedatives and source of resins, gum resins, flavouring agents, foods and even poisons [3].

A. graveolens $\mathrm{L}$. (celery) belongs to the family Apiaceae is a hapaxanthic herb, grown as a biennial and under certain conditions, as an annual with height of 60 to $90 \mathrm{~cm}$. It has a shallow tape root system the stem is branched succulent and ridged. The leaflets are ovate to 
sub orbicular three lobes $2-4.5 \mathrm{~cm}$. The inflorescence is a compound umbel. The flowers are small and white. The fruit is schizocarp, with two mericarps [4]. It is native of Eurasia and grown as a wild plant. It prefers soils containing sodium chlorides and, therefore, was grown on mainly coastal regions. Today, celery is widely cultivated in the temperate zones as an important garden crop [5].

Celery has been used as a food, and at various times both the whole plant and the seeds have been consumed as a medicine. Celery seed is used as a flavouring agent, either as a whole seed or as celery salt; the ground powder mixed with salt. Volatile oil obtained from seeds is used in the perfume and pharmaceutical industries [6]. It is reported to possess several nutraceutical attributes, such as anticoagulation activity of blood plasma and prevention of cardiovascular diseases [7]. Seed oil was used in combination with other herbs, for reduction of blood pressure [8]. The important flavour constituents of the oil responsible for the typical aroma are 3-n-butyl4,5-dihydrophthalide (sedanenolide), 3-n-butyl phthalide, sedanonic anhydride which are present in very low levels [9].

Limonene is a major constituent of $A$. graveolens $\mathrm{L}$. fruit and aerial parts essential oils. Limonene inhibits the development of spontaneous and chemically induced tumors in pancreas of rodents [10]. Limonene can be also used for relief of heartburn and gastroesophageal reflux disorder because of its gastric-acid neutralizing effect and improvement of peristalsis [11].

Phenolic compounds are secondary metabolites which synthesize in plants. They possess biological properties such as: antioxidant, antiapoptosis, anti-aging, anticarcinogen, antiinflammation, anti-atherosclerosis, cardiovascular protection, improvement of the endothelialfunction, as well as inhibition of angiogenesis and cell proliferation activity [12]. The antimutagenic, antibacterial, antiviral, antiinflammatory and antithrombotic actions of flavonoids are well characterized [13].

Due to the high economic potentialities of Apium graveolens L. in particular the medicinal value, the present study was undertaken to add more information on its associated flora as well as volatile oil yield, composition and the phenolic and flavonoid content of the aerial parts and fruits in relation to soil variables. This will be useful to the optimal feasibility of the cultivation of A. graveolens L. as medicinal plant. Results will be important as an indication of the potential economic utility of $A$. graveolens L. as a raw material for useful pharmaceutical phenolic and flavonoidal compounds as well as oil component, such as Limonene.

\section{Materials and methods}

\section{Study area}

Damietta Province is a part of the Nile Delta, it located in the downstream part of the Damietta branch of the River Nile at $31^{\circ} 25^{\prime} 10^{\prime \prime}$ north to $31^{\circ} 48^{\prime} 54^{\prime \prime}$ east N-32 ${ }^{\circ} 30^{\prime}$ longitude to the north east of the Nile Delta region of Egypt. The total average area of Damietta Province is about 1029 $\mathrm{Km}^{2}$ and the total agricultural area is about 115892 feddans [14]. The present study was carried out at five locations in Damietta (Fig. 1). The climate of the study area is typically Mediterranean type and belongs to the arid province which is characterized by a short dry period [15]. The annual mean rainfall at Damietta is $102 \mathrm{~mm}$. The air temperature varies from $13.3^{\circ}$ $\mathrm{C}$ to $27.4{ }^{\circ} \mathrm{C}$ with warm summer and mild winter. Relative humidity varies from a minimum of 69 $\%$ during summer to a maximum of $84 \%$ during winter [16].

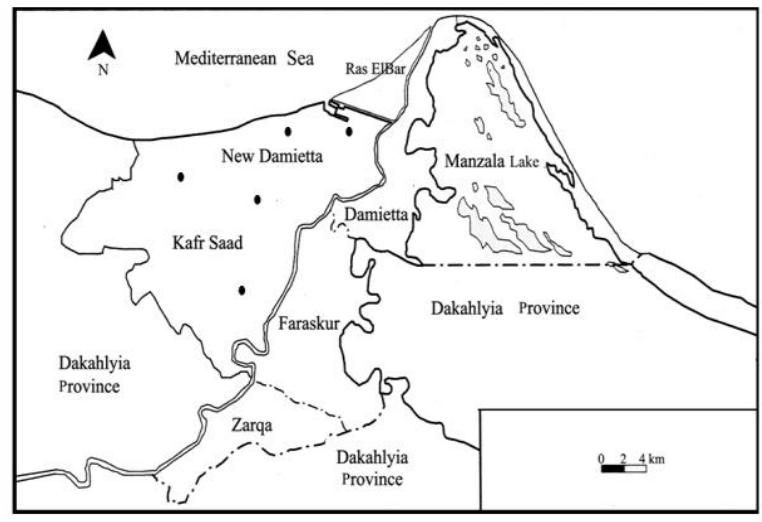

Fig. 1 Location map of Damietta showing the different habitats where Apium graveolens and soil samples were collected.

Apium graveolens L. was collected from five sites represented five different habitats types in Damietta. These habitats were namely: Irrigation canal banks (I), Orchards, cultivated with date palm trees and guava, (II), Sandy fertile cultivated lands, cultivated with vegetables like tomato, (III), reclaimed lands, cultivated with guava, (IV) and waste lands (V). 


\section{Field study}

Five individuals of Apium graveolens L. were sampled and soil samples were collected from the rhizosphere of the target species. In each habitat the associated species were recorded and voucher specimens were identified and deposited in the Herbarium of the Botany Department, Faculty of Science Damietta University, Egypt. Identification and nomenclature of the plants were following [17-20].

\section{Laboratory analyses}

Soil samples were air dried, passed through $2 \mathrm{~mm}$ sieve and analyzed for $\mathrm{pH}$, conductivity (EC), calcium carbonates, chlorides, bicarbonates and the organic carbon, following the procedures of United States Salinity Laboratory [21-23]. Concentrations of the cations: $\mathrm{Na}^{+}, \mathrm{K}^{+}, \mathrm{Ca}^{+2}$ and $\mathrm{Mg}^{+2}$ were determined using a Corning 410 Flame Photometer Model Jenway PFP7 [24].

\section{Essential oil isolation}

Essential oils from each plant material $(50 \mathrm{~g})$ were freshly powdered and steam-distillated for about 6 hours. The obtained oil was dried over anhydrous sodium sulfate. The steam distilled oils were subjected to GC/MS analysis.

\section{GC/MS analysis of the essential oils}

GC/MS analysis for the essential oils was carried out using Thermo Focus GC/DSQII MS plus equipped with a capillary column TR5 5\% phenyl methyl polysiloxane column $(30 \mathrm{~m} \times 0.25 \mathrm{~mm}$ i.d. x 0.25 um film thickness) (Thermo Electron Corporation). Temperature programming was performed at a rate $3^{\circ} \mathrm{C} \mathrm{min}{ }^{-1}$ from $50^{\circ} \mathrm{C}-275^{\circ} \mathrm{C}$ then adjusted at $275{ }^{\circ} \mathrm{C}$. Carrier gas (Helium) flow rate was $20 \mathrm{ml} \mathrm{min}^{-1}$., separation oven temp. $220{ }^{\circ} \mathrm{C}$, surge pressure $3 \mathrm{kPa}$, ionization potential, $70 \mathrm{eV}$ and $\mathrm{m} / \mathrm{z} 40$ to 350 .

\section{Volatile components identification}

The different components were identified by their retention times and mass spectral data, as well as comparison with published data $[25,26]$ or with reference compounds and mass spectrometric libraries of REPLIB and MAINLIB. The percentage composition of the components of the oil was determined by peak area measurements.
Total phenols and total flavonoids estimation.

Total phenolic content was estimated by the Folin-Ciocalteu method [27]. Two hundred micro liters of diluted sample were added to $1 \mathrm{ml}$ of 1:10 diluted Folin-Ciocalteu reagent. After 4 min, 800 $\mu \mathrm{l}$ of saturated sodium carbonate $\left(75 \mathrm{~g} \mathrm{l}^{-1}\right)$ was added. After $2 \mathrm{~h}$ of incubation at room temperature $\left(23{ }^{\circ} \mathrm{C}\right)$, the absorbance at $765 \mathrm{~nm}$ was measured. Gallic acid $\left(0-500 \mathrm{mg} \mathrm{l}^{-1}\right)$ was used for the standard calibration curve. The results were expressed as gallic acid equivalent (GAE) g ${ }^{1}$ dry weight of sample, and calculated as mean value $\pm \mathrm{SD}(\mathrm{n}=3)$

Total flavonoid content was determined using a colorimetric method described by [28]. A dose of $0.25 \mathrm{ml}$ of the extract was mixed with $1.25 \mathrm{ml}$ of distilled water in a test tube, followed by adding $75 \mu \mathrm{l}$ of a $5 \% \mathrm{NaNO}_{2}$ solution. After 6 min, $150 \mu \mathrm{l}$ of a $10 \% \mathrm{AlCl}_{3} .6 \mathrm{H} 2 \mathrm{O}$ solution was added and allowed to stand for another $5 \mathrm{~min}$ before adding $0.5 \mathrm{ml}$ of $1 \mathrm{M} \mathrm{NaOH}$. The mixture was brought to $2.5 \mathrm{ml}$ with distilled water and mixed well. The absorbance was measured immediately against the blank at $510 \mathrm{~nm}$ using a UV-Visible Spectrophotometer. The results were calculated and expressed as micrograms of catechol equivalents ( $\mathrm{mg}$ of CAE $\mathrm{g}^{-1}$ dry weight of sample) using the calibration curve of catechol. Linearity range of the calibration curve was 10 to $1000 \mu \mathrm{g} \mathrm{ml}^{-1}$ ( $\left.\mathrm{r}=0.99\right)$.

\section{Statistical analysis}

Analysis of variance (ANOVA) was performed by using SPSS program (2009) (version 18). Means were separated according to the Tukey's multiple range tests. Pearson's correlation (r) was performed using SPSS program (version 18).

\section{Results}

Apium graveolens $\mathrm{L}$. had a wide range of habitats in the Nile Delta. Apium graveolens L. was collected from five sites represented five different habitats types. These habitats were namely: Irrigation canal banks (I), Orchards, cultivated with date palm trees and guava, (II), Sandy fertile cultivated lands, cultivated with vegetables like tomato, (III), reclaimed lands, cultivated with guava, (IV) and finally waste lands $(\mathrm{V})$.

Total number of associated plant species 
growing with Apium graveolens L. was 16 species related to 8 families. Asteraceae comprises 4 species $(25 \%)$ of the total recorded species 3 annuals Sonchus oleraceus; Chicorium endivia and Conyza aegyptiaca and 1 perennials Pluchea discoridis, followed by Fabaceae (18.75\%), included two annuals Trifolium resupinatum and Meliotus indicus one perennial Lotus glaber. Poaceae (12.5\%) Cynodon dactylon; Phragmites australis 2 annual species. Polygonaceae (12.5\%) and Chenopodiaceae (12.5\%) had 2 annual species also. Cyperaceae, Apiaceae and Euphorbiaceae had 1 species Emex spinosa; Rumex dentatus belonging to Polygoniaceae, Chenopodiaceae also had 2 annuals Chenopodium murale; Beta vulgaris, while Apiaceae, Euphorbiaceae and Cyperaceae each had only one species each $(6.25 \%)$ of the total recorded species. Apiaceae and Euphorbiaceae each had an annual species Ammi majus, and Euphorbia peplum and while the perennial species Cyperus rotundus L. belongs to family Cyperaceae.

Life forms of the associated species with Apium graveolens L. were mainly therophytes (68.75\%), followed by geophytes (18.75), phanerophytes and hemicryptophytes each (6.25\%).

The $\mathrm{pH}$ of soil supporting Apium graveolens L. ranged from 6.6 to 7.1. EC ranged from 2.45 to $4.15\left(\mathrm{mS} \mathrm{cm}^{-1}\right) . \mathrm{CaCO}_{3}$ percentages ranged from 6.96 to $30.58 \%$. The O.C content of soil supporting Apium graveolens L. ranged from 0.32 to $1.76 \%$. Bicarbonates ranged from 0.04 to $0.14 \% . \mathrm{Cl}^{-}$ion ranged from 0.07 to $0.35 \%$. $\mathrm{Na}^{+}$ content of soil supports Apium graveolens L. ranged from 8.86 to $11.36 \mathrm{mg} 100 \mathrm{~g}^{-1}$ soil. $\mathrm{K}^{+}$ content ranged from 7.23 to $8.8 \mathrm{mg} 100 \mathrm{~g}^{-1}$ soil. $\mathrm{Mg}^{+2}$ content ranged from 5.76 to $11.23 \mathrm{mg} 100$ $\mathrm{g}^{-1}$ soil. $\mathrm{Ca}^{+2}$ content of soil supports Apium

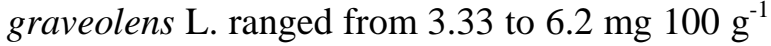
soil (Table 1). Analysis of variance (ANOVA) results (Table 1) revealed that the mean values of all the measured variables were significantly different at probability level of less than 0.001 and bicarbonates percentage of the soil samples of Apium graveolens $\mathrm{L}$. which showed significant difference at a probability level equal 0.001, except potassium content of the soil samples of Apium graveolens L. which had non significant difference at a probability level of 0.064 .

Table 1. Means \pm SD and ANOVA-One way of soil variables of Apium graveolens L. in different sites. Means having different small letters are significantly different according to Tukey's test. (E.C= Conductivity, O.C $=$ Organic Carbon, $\mathrm{SD}=$ Standard Deviation)

\begin{tabular}{|c|c|c|c|c|c|c|c|}
\hline \multirow[t]{2}{*}{ Soil variable } & \multicolumn{5}{|c|}{ Means \pm SD in each site } & \multirow[t]{2}{*}{ F ratio } & \multirow[t]{2}{*}{$\mathrm{P}$} \\
\hline & I & II & III & IV & $\mathrm{V}$ & & \\
\hline $\mathrm{pH}$ & $6.72 \pm 0.02^{\mathrm{a}}$ & $81 \pm 0.01^{\mathrm{a}}$ & $6.60 \pm 0.00^{\mathrm{a}}$ & $7.11 \pm 0.01^{b}$ & $6.61 \pm 0.01^{\mathrm{a}}$ & 1124.17 & 0.000 \\
\hline E.C $\left(\mathrm{mS} \mathrm{cm}^{-1}\right)$ & $2.45 \pm 0.05^{\mathrm{a}}$ & $3.35 \pm 0.63^{b}$ & $4.15 \pm 1.17^{\mathrm{c}}$ & $3.10 \pm 0.48^{\mathrm{d}}$ & $3.40 \pm 0.77^{\mathrm{b}}$ & 52 & 0.000 \\
\hline$\% \mathrm{CaCO}_{3}$ & $30.58 \pm 0.53^{\mathrm{a}}$ & $21.75 \pm 0.42^{\mathrm{b}}$ & $11.68 \pm 0.45^{\mathrm{c}}$ & $6.96 \pm 0.25^{\mathrm{d}}$ & $21.63 \pm 0.40^{\mathrm{b}}$ & 42.88 & 0.000 \\
\hline$\%$ O.C & $1.06 \pm 0.03^{\mathrm{a}}$ & $0.32 \pm 0.03^{\mathrm{b}}$ & $0.84 \pm 0.06^{\mathrm{c}}$ & $1.76 \pm 0.12^{\mathrm{d}}$ & $0.18 \pm 0.06^{\mathrm{e}}$ & 209.94 & 0.000 \\
\hline$\% \mathrm{HCO}_{3}^{-}$ & $0.11 \pm 0.017^{\mathrm{a}}$ & $0.04 \pm 0.01^{\mathrm{b}}$ & $0.070 .017 \pm^{\mathrm{c}}$ & $0.14 \pm 0.01^{\mathrm{a}}$ & $0.06 \pm 0.01^{\mathrm{c}}$ & 10.10 & 0.001 \\
\hline $\mathrm{Cl}^{-}$ & $0.07 \pm 0.00^{\mathrm{a}}$ & $0.17 \pm 0.00^{\mathrm{b}}$ & $0.17 \pm 0.00^{\mathrm{b}}$ & $0.35 \pm 0.00^{\mathrm{c}}$ & $0.19 \pm 0.00^{\mathrm{b}}$ & 1599.08 & 0.000 \\
\hline${ }^{-1}$ soil) & $11.36 \pm 0.15^{\mathrm{a}}$ & $8.86 \pm 0.05^{\mathrm{b}}$ & $10.40 \pm 0.10^{\mathrm{c}}$ & $10.26 \pm 0.15^{\mathrm{c}}$ & $9.46 \pm 0.05^{\mathrm{d}}$ & 178.76 & 0.000 \\
\hline $\mathrm{K}^{+}\left(\mathrm{mg} 100 \mathrm{~g}^{-1}\right.$ soil $)$ & $7.23 \pm 0.05$ & $7.93 \pm 1.61$ & $7.53 \pm 0.15$ & $8.80 \pm 0.00$ & $8.80 \pm 0.10$ & 2.842 & 0.064 \\
\hline $\mathrm{Mg}^{+2}\left(\mathrm{mg} 100 \mathrm{~g}^{-1}\right.$ soil $)$ & $5.76 \pm 0.05^{\mathrm{a}}$ & $11.23 \pm 0.15^{\mathrm{b}}$ & $9.13 \pm 0.05^{\mathrm{c}}$ & $9.93 \pm 0.15^{\mathrm{d}}$ & $10.4 \pm 0.10^{\mathrm{e}}$ & 639.35 & 0.000 \\
\hline $\mathrm{Ca}^{+2}\left(\mathrm{mg} 100 \mathrm{~g}^{-1}\right.$ soil $)$ & $3.33 \pm 0.15^{\mathrm{a}}$ & $4.16 \pm 0.15^{b}$ & $4.73 \pm 0.20^{c}$ & $5.66 \pm 0.15^{\mathrm{d}}$ & $6.20 \pm 0.10^{\mathrm{e}}$ & 169.26 & 0.000 \\
\hline
\end{tabular}

Pearson's correlation coefficients among soil variables in the surveyed sites from which Apium graveolens L were collected are illustrated in Table 2. Sixteen of the forty five coefficients highlighted significant correlation. A very high positive correlation coefficient was found between the percentage of soil bicarbonates and sodium of the soil extract $\left(\mathrm{r}=0.860^{* *}\right)$. Meanwhile, there was a high negative correlation coefficient between sodium content and magnesium content of the soil extract ( $r=-$

\section{$\left.0.896^{* *}\right)$.}

Of the 21 distinguishable compounds detected across the aerial parts oil samples by GC/MS analysis, limonene was consistently the most abundant (see Table 3). Proportions of this constituent in total aerial parts oil fractions ranged from relatively low value $41.02 \%$ for habitat II, through $46.12 \%$ for habitat (V), 49.19 for habitat (IV) and $70.7 \%$ for habitat (I) respectively to a higher maximum value $84.94 \%$ for habitat III. Other principle constituents that 
present at much lower concentrations are $\alpha$ myrcene (9.64-26.30\%), $\alpha$-farnesene $(2.65-$ $6.81 \%)$ and sedanenolide (4.29-15.57\%). These constituents occurred in inverse proportion to the concentration of limonene.

Table 2. Multiple correlation coefficient(r) between soil variables supporting the growth of Apium graveolens L. in Damietta. $(*=\mathrm{p} \leq 0.05, * *=\mathrm{p} \leq 0.01)$

\begin{tabular}{|c|c|c|c|c|c|c|c|c|c|}
\hline $\mathrm{pH}$ & E.C & $\% \mathrm{CaCO}_{3}$ & $\%$ O.C & $\% \mathrm{HCO}_{3}^{-}$ & $\mathrm{Cl}^{-}$ & $\mathrm{Na}^{+}$ & $\mathrm{K}^{+}$ & $\mathrm{Mg}^{+2}$ & $\mathrm{Ca}^{+2}$ \\
\hline $\mathrm{pH}$ & $-0.706^{* * *}$ & 0.094 & $0.654^{* *}$ & $0.532^{*}$ & 0.284 & 0.005 & 0.312 & 0.298 & 0.422 \\
\hline E.C $\left(\mathrm{mS} \mathrm{cm}^{-1}\right)$ & 1 & $-0.586^{*}$ & -0.339 & -0.391 & 0.358 & -0.254 & -0.072 & 0.131 & 0.076 \\
\hline$\% \mathrm{CaCO}_{3}$ & & 1 & -0.384 & -0.191 & $-0.864^{* *}$ & 0.146 & -0.301 & -0.375 & $-0.471^{*}$ \\
\hline$\% \mathrm{O} . \mathrm{C}$ & & & 1 & $0.860^{* * *}$ & 0.383 & $0.597^{* *}$ & 0.045 & -0.287 & 0.001 \\
\hline$\% \mathrm{HCO}_{3}$ & & & & 1 & 0.290 & $0.608^{* *}$ & 0.061 & -0.370 & 0.066 \\
\hline $\mathrm{Cl}^{-}$ & & & & & 1 & -0.300 & $-0.531^{*}$ & $0.487 *$ & $0.616^{* *}$ \\
\hline \multicolumn{3}{|c|}{$\mathrm{Na}^{+}\left(\mathrm{mg} 100 \mathrm{~g}^{-1}\right.$ soil $)$} & & & & 1 & -0.384 & $-0.896^{* *}$ & -0.404 \\
\hline \multicolumn{2}{|c|}{$\mathrm{K}^{+}\left(\mathrm{mg} 100 \mathrm{~g}^{-1}\right.$ soil $)$} & & & & & & 1 & $0.487 *$ & $0.659^{* *}$ \\
\hline \multicolumn{2}{|c|}{$\mathrm{Mg}^{+2}\left(\mathrm{mg} 100 \mathrm{~g}^{-1}\right.$ soil $)$} & & & & & & & 1 & $0.636^{* *}$ \\
\hline \multicolumn{2}{|c|}{$\mathrm{Ca}^{+2}\left(\mathrm{mg} 100 \mathrm{~g}^{-1}\right.$ soil $)$} & & & & & & & & 1 \\
\hline
\end{tabular}

Table 3. Volatile oil content from aerial parts of Apium graveolens $\mathrm{L}$

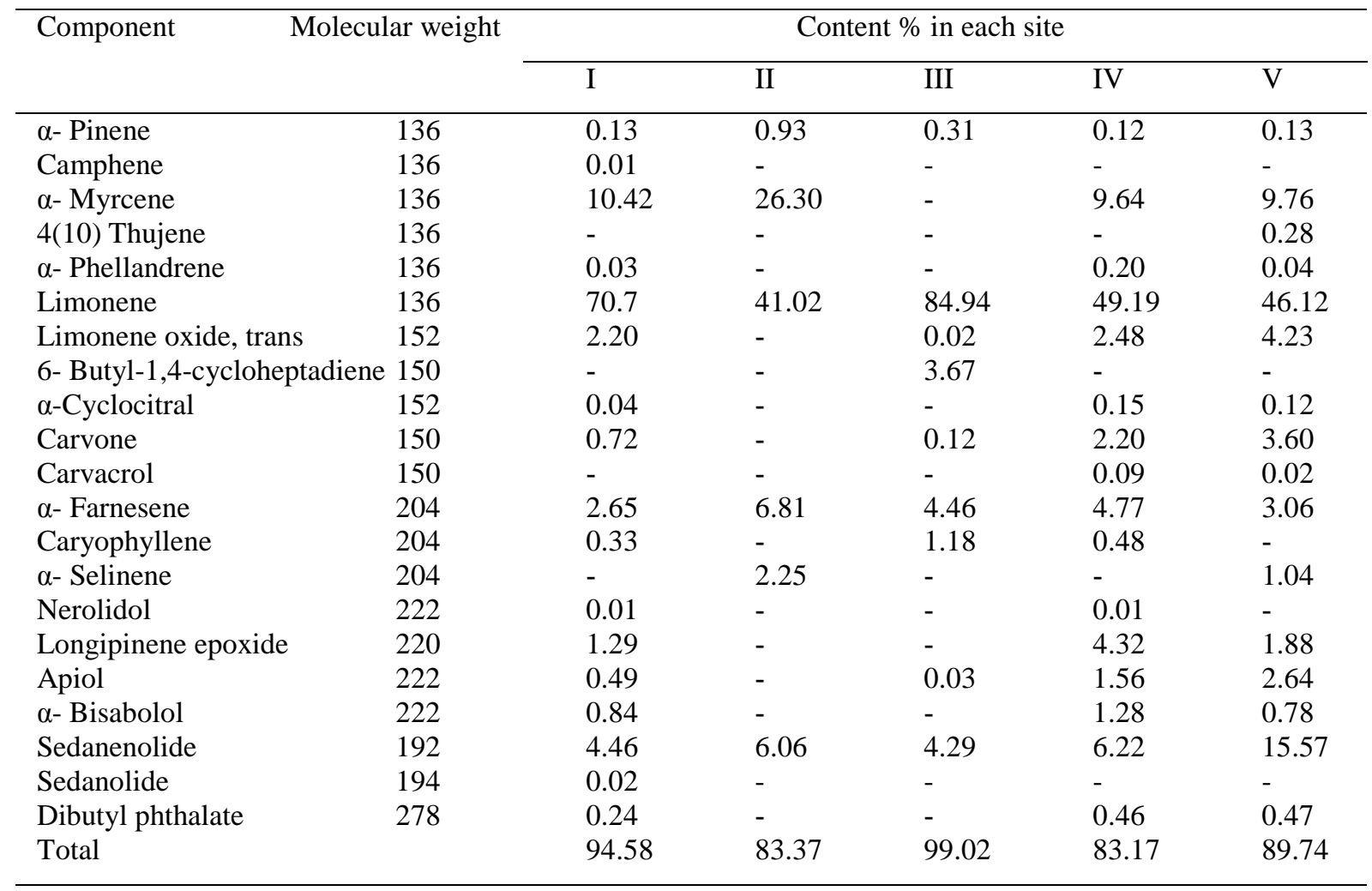

In the celery fruits volatile oils 15 components were isolated and characterized by GC/MS (Table 4). Limonene was generally the main constituent (81.07-89.81\%) and sedanenolide was the second most dominant constituent (4.05$12.41 \%)$. 6-butyl-1,4-cycloheptadiene and $\alpha$ Selinene also occurred in substantial amounts (0.06-4.38\%).The quantitative composition of the volatile fraction of the fruits varies widely depending on the region of cultivation.

The yield percentage of the oil from aerial parts and fruits of Apium graveolens L. was shown in Table 5.

The total phenol and flavonoid contents of aerial parts and fruits of Apium graveolens L. varied widely according to the production area as shown in table 6 and table 7 respectively.

The relationships between soil variables and volatile oil content of Apium graveolens L. aerial parts and fruits, (Fig. 2) and (Fig. 3), respectively suggested that soil salinity (EC), calcium carbonates, organic carbon, $\mathrm{Na}^{+}, \mathrm{K}^{+}, \mathrm{Mg}^{+2}, \mathrm{Ca}^{+2}$ 
and $\mathrm{Cl}^{-}$are the most important factors affecting the volatile oil content.

\section{Discussion}

Field study indicated that Apium graveolens L. had a wide range of habitats in Nile Delta namely sandy fertile cultivated lands, irrigation canals
[29], Orchards, reclaimed lands and waste land. Soil analysis indicated that Apium graveolens L. grow in a wide range of soil variables such as electric conductivity, calcium carbonate, organic carbon, chloride ion, potassium, sodium, calcium and magnesium cations. In the present study there was a significantly correlation between soil variables with each other.

Table 4. Volatile oil content from fruits of Apium graveolens L.

\begin{tabular}{lllllll}
\hline Component & Molecular weight & \multicolumn{5}{c}{ Content \% in each site } \\
\cline { 3 - 7 } & & I & II & III & IV & V \\
\hline$\alpha$ - Pinene & 136 & 0.01 & - & 0.57 & 0.54 & 1.22 \\
$\alpha$ - Myrcene & 136 & 0.30 & 0.99 & 0.38 & 0.82 & - \\
Limonene & 136 & 84.93 & 88.62 & 87.42 & 89.81 & 81.07 \\
$\alpha$ - Linalool & 154 & - & - & - & 0.06 & 0.17 \\
cis- Limonene oxide & 152 & 0.02 & 0.01 & 0.02 & 0.02 & 0.10 \\
6-Butyl-1,4- cycloheptadiene & 150 & 3.67 & 2.02 & 2.31 & 0.77 & 2.28 \\
$\alpha$-Terpineol & 154 & 0.01 & 0.01 & - & - & 0.05 \\
Carvone & 150 & 0.12 & 0.09 & 0.11 & 0.02 & 0.05 \\
4- hydroxyl-2- methylacetophenone & 150 & 0.12 & 0.06 & 0.07 & 0.04 & 1.07 \\
Caryophyllene & 204 & 1.14 & 0.90 & 1.03 & 0.02 & 0.06 \\
$\alpha-$ Farnesene & 204 & 0.07 & 0.04 & 0.05 & 0.03 & - \\
$\alpha-$ Selinene & 204 & 4.38 & 2.70 & 2.57 & 0.06 & 0.12 \\
Patchoulane & 206 & 0.03 & 0.02 & 0.03 & - & 0.09 \\
Apiol & 222 & 0.03 & 0.02 & 0.02 & 0.02 & 0.03 \\
Sedanenolide & 192 & 4.29 & 4.05 & 5.01 & 7.33 & 12.41 \\
Di-n-octyl phthalate & 390 & 0.04 & 0.07 & 0.02 & 0.09 & 0.05 \\
Total & & 99.16 & 99.60 & 99.61 & 99.63 & 98.77 \\
\hline
\end{tabular}

Table 5. Yield percentage of the oil from aerial parts and fruits of Apium graveolens $\mathrm{L}$.

\begin{tabular}{lcc}
\hline Sites & $\begin{array}{l}\text { \% Oil yield } \\
\text { of aerial parts }\end{array}$ & $\begin{array}{l}\text { \% Oil yield } \\
\text { of fruits }\end{array}$ \\
\hline & & \\
I & 0.2 & 3.0 \\
II & 0.2 & 2.2 \\
III & 0.8 & 2.0 \\
IV & 0.2 & 1.2 \\
V & 0.4 & 1.5 \\
\hline
\end{tabular}

Table 6. The phenolic and flavonoid contents of the aerial parts of Apium graveolens L.

\begin{tabular}{lcc}
\hline Sites & $\begin{array}{l}\text { Phenolics } \\
\text { mg (GAE) } g^{-1} \text { dry } \\
\text { weight of sample }\end{array}$ & $\begin{array}{l}\text { Flavonoids } \\
\text { mg (GAE) } g^{-1} \text { dry } \\
\text { weight of sample }\end{array}$ \\
\hline I & 36.435 & 5.943 \\
II & 30.075 & 2.044 \\
III & 18.7171 & 1.115 \\
IV & 16.105 & 2.044 \\
V & 35.186 & 1.672 \\
\hline
\end{tabular}

Table 7. The phenolic and flavonoid contents of the fruits of of Apium graveolens L.

\begin{tabular}{lcc}
\hline Sites & $\begin{array}{l}\text { Phenolics } \\
\text { mg (GAE) } \mathrm{g}^{-1} \text { dry } \\
\text { weight of sample }\end{array}$ & $\begin{array}{l}\text { Flavonoids } \\
\text { mg (GAE) } \mathrm{g}^{-1} \text { dry } \\
\text { weight of sample }\end{array}$ \\
\hline I & 0.772 & Nil \\
II & 0.205 & Nil \\
III & 0.091 & Nil \\
IV & 3.725 & 0.373 \\
V & 0.772 & Nil \\
\hline
\end{tabular}

The relationships between soil variables and volatile oil content of Apium graveolens L. aerial parts and fruits, indicated that soil salinity (EC), calcium carbonates, organic carbon, $\mathrm{Na}^{+}, \mathrm{K}^{+}$, $\mathrm{Mg}^{+2}, \mathrm{Ca}^{+2}$ and $\mathrm{Cl}^{-}$are the most important factors affecting the volatile oil content. Some researchers reported that, potassium fertilization increased most vegetative parameters, fruit yield, oil yield, as well as chemical constituents in fruits and leaves especially $\mathrm{K}^{+}$content in fennel and other 
Umbelliferae plants [30]. Oil content in the seeds of sweet fennel decreased progressively with increase in salinity [31]. Organic fertilizers $(2.5 \mathrm{~kg}$ $\mathrm{m}^{-2}$ ) considerably increased oil yield of fennel [32].

In the present study, by the GC/MS analysis for the essential oils of aerial parts of Apium graveolens $\mathrm{L}$. indicated that the major component of volatile oil was limonene. Dietary limonene has been shown to be capable of preventing the development and causing the regression of chemically induced mammary carcinomas, causing $80 \%$ carcinomas to regress with little host toxicity [33]. At a dose of $100 \mathrm{mg} \mathrm{kg}^{-1}$ given to
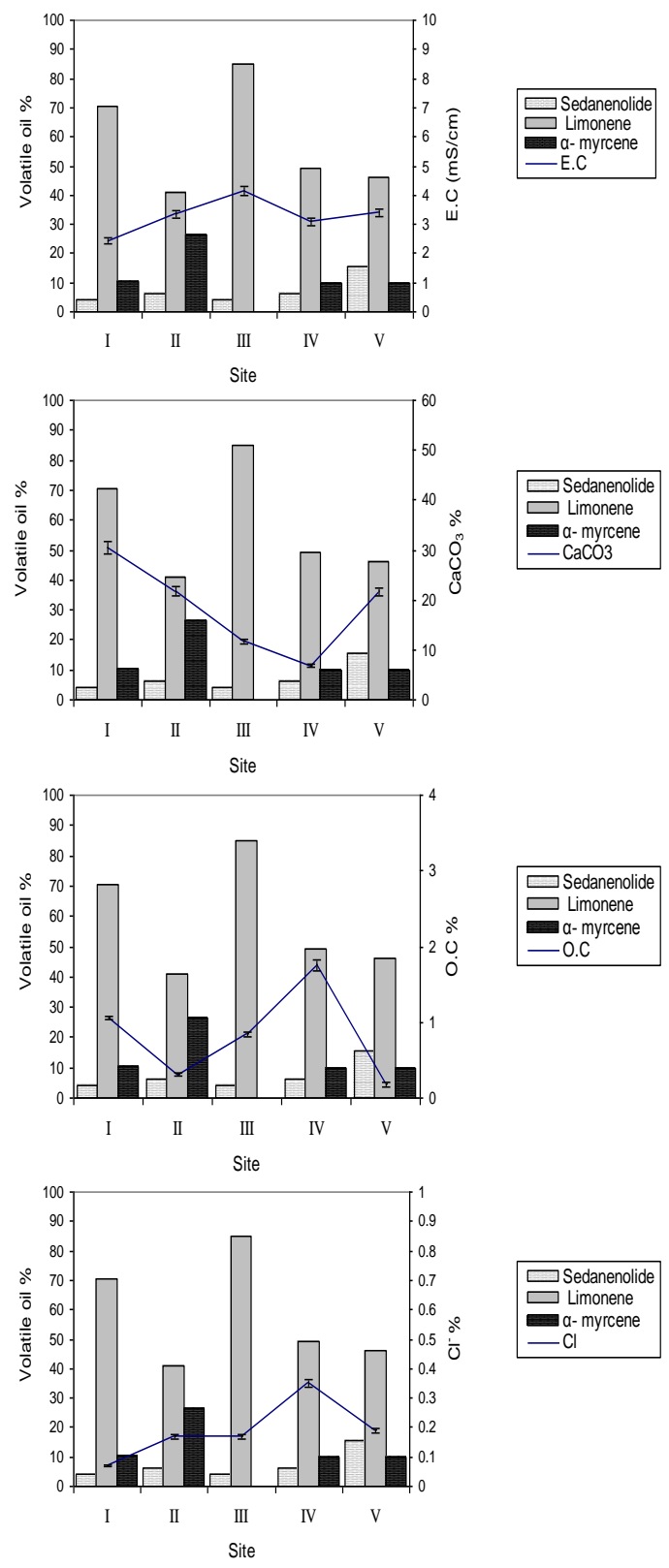

human volunteers, limonene caused no toxicity [33]. D-limonene is well tolerated in cancer patients at a dose that may have clinical activity [34]. As could be expected from its higher limonene content which has a great medicinal values, habitat III, a sandy fertile cultivated lands with EC $4.15\left(\mathrm{mS} \mathrm{cm} \mathrm{cm}^{-1}\right)$, calcium carbonate percentage $11.68 \%$, organic carbon percentage $0.84 \%, \mathrm{Cl}^{-}$percentage $0.17 \%, \mathrm{Na}^{+}$content 10.4 $\left(\mathrm{mg} 100 \mathrm{~g}^{-1}\right.$ soil $), \mathrm{K}^{+}$content $7.53\left(\mathrm{mg}^{-100 \mathrm{~g}^{-1}}\right.$ soil) and $\mathrm{Mg}^{+2}$ content $9.13\left(\mathrm{mg} 100 \mathrm{~g}^{-1}\right.$ soil), is the site of choice for planting of celery aerial parts.
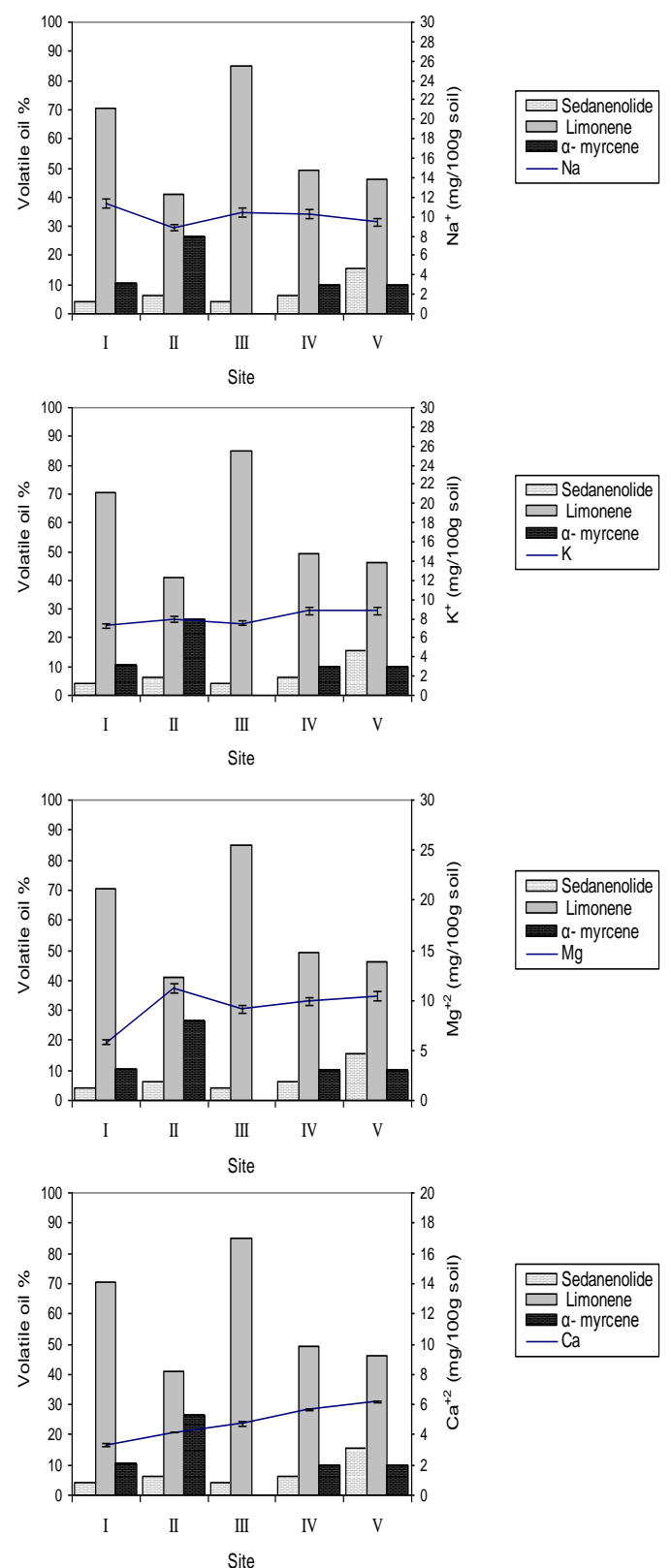

Fig. 2 Soil variables _ volatile oil content relationships of Apium graveolens L. aerial parts in different sites. (E.C $=$ conductivity, $\mathrm{O} . \mathrm{C}=$ organic carbon). 
GC/MS analysis for the essential oils of fruits of Apium graveolens L. showed that Limonene was generally the main constituent and sedanenolide was the second most dominant constituent [35]. Concerning the high percentage of limonene, habitat IV, reclaimed lands with EC
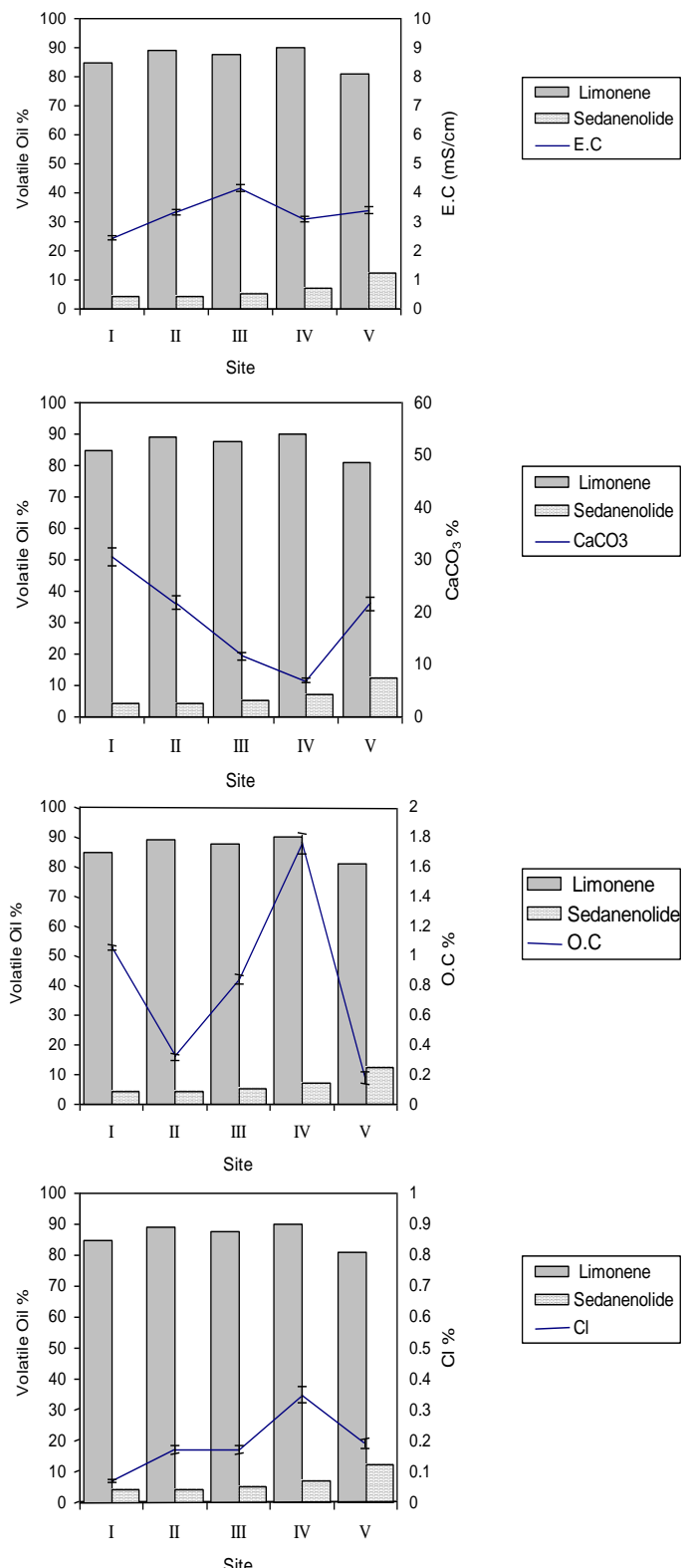

Fig. 3 Soil variables _ volatile oil content relationships of Apium graveolens L. fruits in different sites. (E.C= conductivity, O.C $=$ organic carbon).

Maximizing the oil yields had been identified as a powerful means of increasing profitability of the industry, habitat III (sandy fertile cultivated lands) and habitat I (irrigation canal banks) had the highest volatile oils yields of the aerial parts and fruits, respectively.

Arial parts and fruits growing in habitat I (irrigation canal banks) and habitat IV (reclaimed
$3.10\left(\mathrm{mS} \mathrm{cm}^{-1}\right)$, calcium carbonate percentage $6.96 \%$, organic carbon percentage $1.76 \%, \mathrm{Cl}^{-}$ percentage $0.35 \%, \mathrm{Na}^{+}$content $10.26\left(\mathrm{mg}^{100 \mathrm{~g}^{-1}}\right.$

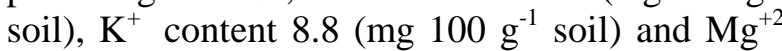
content $9.93\left(\mathrm{mg} 100 \mathrm{~g}^{-1}\right.$ soil), is the site of choice.
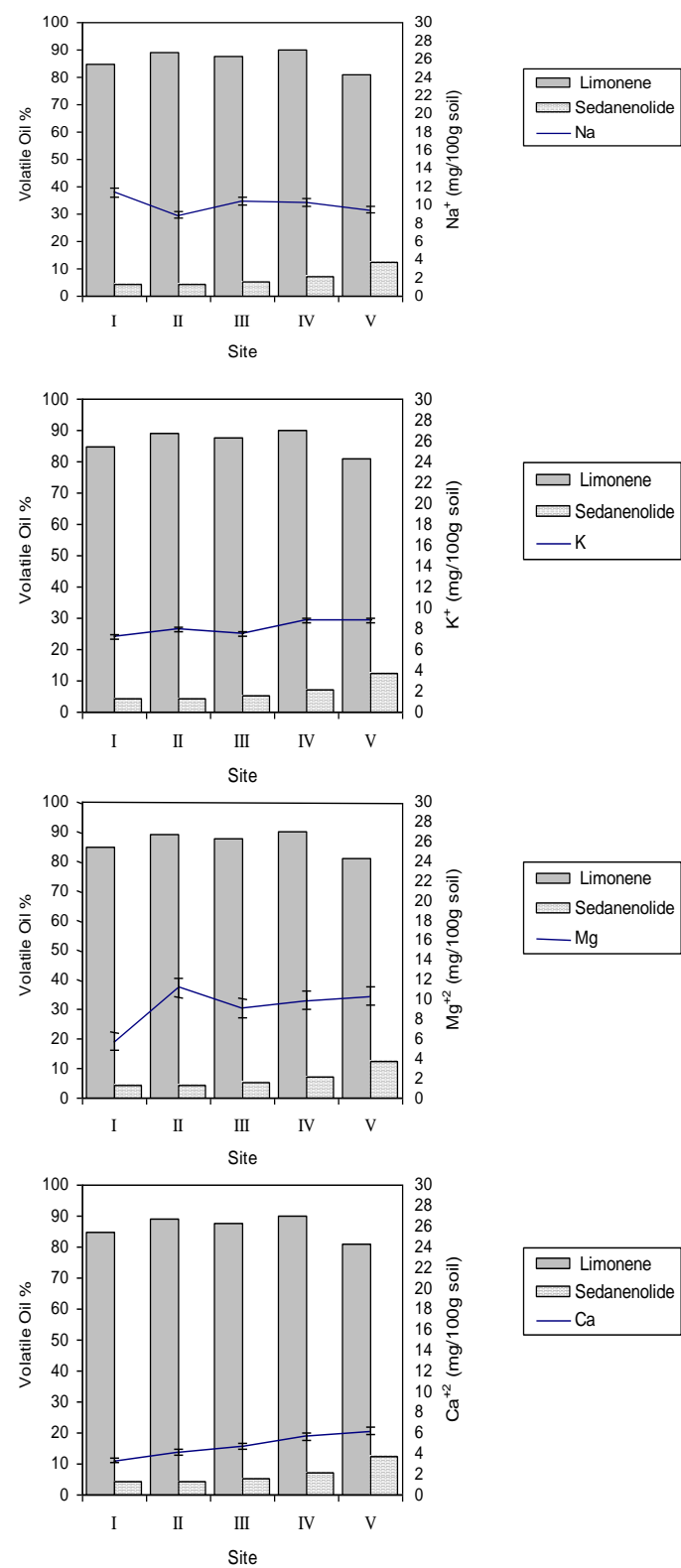

lands), respectively, showed the highest values in total phenol and flavonoid content.

Briefly, this study has attempted to integrate information concerning soil types and chemical features on one hand and plants having some industrial potentialities on the other. It has highlighted the evidence that soil composition and characteristics may affect qualitative parameters 
of herbal products. Field study indicated that xerophytes, geophytes, hemicryptophytes and phanerophytes were the main life forms of the associated species with Apium graveolens L. The major controlling soil variables affecting the yield and composition of volatile oil and total phenol and flavonoid contents of celery fruits and aerial parts were electric conductivity, calcium carbonate, organic carbon, chlorides, potassium, sodium, calcium and magnesium cations. From the above, the following facts can be concluded: 1) The fruits of $A$. graveolens L. growing in reclaimed lands showed the highest limonene, total phenol and flavonoid contents. 2) The aerial parts of A. graveolens L. growing in sandy fertile cultivated lands were characterized by their highest limonene content, while, those growing in irrigation canal banks, showed the highest values in total phenol and flavonoid contents. 3) The growing of A. graveolens $\mathrm{L}$. in waste lands greatly affected the quantitative composition of the volatile oils of both fruits and aerial parts as oils exhibited a strong drop in limonene content and a dramatic increase in sedanenolide content. Findings of this research help management and planting of this medicinal plant.

\section{Acknowledgements}

The authors are grateful to Damietta University for providing the facilities for conducting this research.

\section{References}

[1] V.H. Heywood, Flowering plants of the world. Equinox (oxford) Ltd. Littlegate House, Oxford, England (1985) 219-221

[2] L. Boulos, Flora of Egypt. Volume II. Al Hadara Publishing Cairo, Egypt (2000)

[3] M. Hickey, C. King, Common families of flowering plants. Cambridge Univerisity Press (1998) 107

[4] R.P. Rastogi, B.N. Mehrota, S. Sinha, P. Pant, R. Seth, Compendium of Indian medicinal plants, Vol. V. CDRI Lucknow and National Institute of Science and communication (1994) 757

[5] U. Salzer, On the fatty acid composition of the non-volatile lipoids of some spices, Fette Seifen Anstrichm 77 (1975) 446-452

[6] Y.S. Lewis, Spices and herbs for food industry, London. Food Trade press (1984).

[7] S. Brankovic, D. Kitic, M. Radenovic, S. Veljkovic, M. Kostic, B. Miladinovic, D.
Pavlovic, Hypotensive and cardioinhibotory effects on the aqueous and ethanol extracts of Celery (Apium graveolens, Apiaceae). Acta Medica Medianae 49 (2010) 13-16

[8] S.S. Fazal, R.K. Singla, Review on the pharmacognostical and pharmacological characterization of Apium graveolens Linn Indo. Global Journal of Pharmaceutical Sciences 2 (2012) 36-42

[9] H.B. Sowbhagya, S.R. Sampathu, N. Krishnamurthy, Evaluation of size reduction on the yield and quality of celery seed, Journal of Food Engineering 80 (2007) 1255-1260

[10] A. Nakaizumi, M. Baba, H. Uehara, H. Iishi, M. Tatsuta, D-Limonene inhibits N-nitrosobis (2oxopropyl) amine induced hamster pancreatic carcinogenesis, Cancer Letters. 117(1997) 99103

[11] A. Rozza, T. Moraes, H. Kushima, A. Tanimoto, M. Marques, T. Bauab, C. Hiruma-Lima, C. Pellizzon, Gastroprotective mechanisms of Citrus lemon (Rutaceae) essential oil and its majority compounds limonene and $\beta$-pinene: Involvement of heat-shock protein-70, vasoactive intestinal peptide, glutathione, sulfhydryl compounds, nitric oxide and prostaglandin E2, Chemico-Biological Interactions 189 (2011) 82-89

[12] X. Han, T. Shen, H. Lou, Dietary polyphenols and their biological significance. International Journal of Molecular Science 8 (2007) 950-988

[13] C. Mario, P. Luc, V. Arnold, V.B Dirk, Inhibition of bacterial mutagenesis by Citrus flavonoids. Planta Med. 62 (2006) 222226

[14] I.A. Mashaly, E.F. El-Halawany, G. Omar, Vegetation analysis along irrigation and drain canals in Damietta province, Egypt. Pakistan Journal of Biological Sciences 1 (2001) 11831189

[15] M.A. Ayyad, M. Abdel-Razik, S. Mehanna, Climatic and vegetation gradients in the desert of Egypt. Pre-report of the Mediterranean Bioclimatology Symposium. Montpellier, France (1983) 2-19

[16] M.S. Serag, On the ecology of Damietta coastal area. M.Sc. Thesis, Facaulty Science, Mansoura University Egypt (1986)

[17] V. Täckholm, Students' flora of Egypt. Second edition. Cairo University press (1974)

[18] L. Boulos, Flora of Egypt. Volume I. Al Hadara Publishing Cairo, Egypt (1999)

[19] L. Boulos, Flora of Egypt. Volume III. Al Hadara Publishing Cairo, Egypt (2002)

[20] L. Boulos, Flora of Egypt. Volume VI. Al Hadara Publishing Cairo, Egypt (2005)

[21] Anonymous, Diagnosis and improvement of saline alkaline soils. USDA HandBook 60. Washington D.C. US (1954)

[22] C.S. Piper, Soil and plant analysis, Interscience 
Publisher Inc. New York. Plant growth, scientific publishers. Jodhpur, India. (1947)

[23] M.L. Jackson, Soil chemical analysis. Constable and Co. Ltd, London (1962)

[24] L.D. Rowell, Soil science methods and application. $1^{\text {st }}$ Edition. British Library Cataloging in Publication Data. Longman Group, United Kingdom 182 (1994)

[25] Y. Masada, Analysis of essential oils by gas chromatography and mass spectrometry. John Wiley \& Sons Inc, New York (1976)

[26] R.P. Adams, Identification of essential oil components by gas chromatography/mass spectroscopy. Allured Publishing Corporation. Carol Stream, Illinois, USA. (1995)

[27] V. L. Singleton, J. A. Rossi, Colorimetry of total phenolics with phosphomolybdicphosphotungstic acid reagents. Am. J. Enol. Vitic. 16 (1965) 144-158.

[28] D. Heimler, P. Vignolini, M. G. Dini, A. Romani, Rapid tests to assess the antioxidant activity of Phaseolus vulgaris L. dry beans. Journal of Agricultural and Food Chemistry 53 (2005) 3053-3056

[29] I.A. Mashaly, I.E. El-Habashy, E.F. ElHalawany, G. Omar, Habitat and plant communities in the Nile Delta of Egypt II. Irrigation and drainage canal bank. Pakistan Journal of Biological Sciences 12 (2009) 885895
[30] B.L. Menaria, P.L. Maliwal, Quality of fennel as influenced by plant density, fertilization and plant growth regulators. Indian Journal of Plant Physiology. Indian Society for Plant Physiology. New Delhi. India 12 (2007) 57-62

[31] M. Ashraf, N. Akhtar, Influence of salt stress on growth, ion accumulation and seed oil content in sweet fennel. Biologia Plantarum 48 (2004) 461464

[32] M.A.H. Mohamed, M. Abdu, Growth and oil production of fennel (Foeniculum vulgare Mill.). Effect of irrigation and organic fertilization. Biol. A. Hort. 22 (2004) 31-39

[33] P.L. Crowell, C.E. Elson, H.H. Bailey, A. Elegbede, J.D. Haag, M.N. Gould, Human metabolism of the experimental cancer therapeutic agent D-limonene, Cancer Chemother. Pharmacol 35 (1994) 31-37

[34] D.M. Vigushim, G.K. Poon, A. Boddy, J. English, G.W. Halbert, C. Pagonis, M. Jarman, R.C. Coombes, Phase I and pharmacokinetic study of d-limonene in patients with advanced cancer. Cancer Research Campaign Phase I/II Clinical Trials Committee, Cancer Chemother. Pharmacol. 42 (1998) 111-117

[35] J.M.L. Rao, S. Nagalakshmi, P.J. Naik, N.B. Shankaracharya, Studies on chemical and technolocical aspects of celery (Apium graveolens Linn) seed. Journal of Food Science and Technology 37 (2000) 631-635

$$
\begin{aligned}
& \text { ممدوح سالم سراج1، سحر رفعت جداره²، أمينة زكريا أبو النجاء1، نسمه جلال عامر } 1 \\
& 1 \text { قسم النباتـ كليةٌ العلوم - جامعة دمياط } \\
& 2 \text { قسم العقاقير- كلية الصيدلة ـ جامعة المنصورة }
\end{aligned}
$$

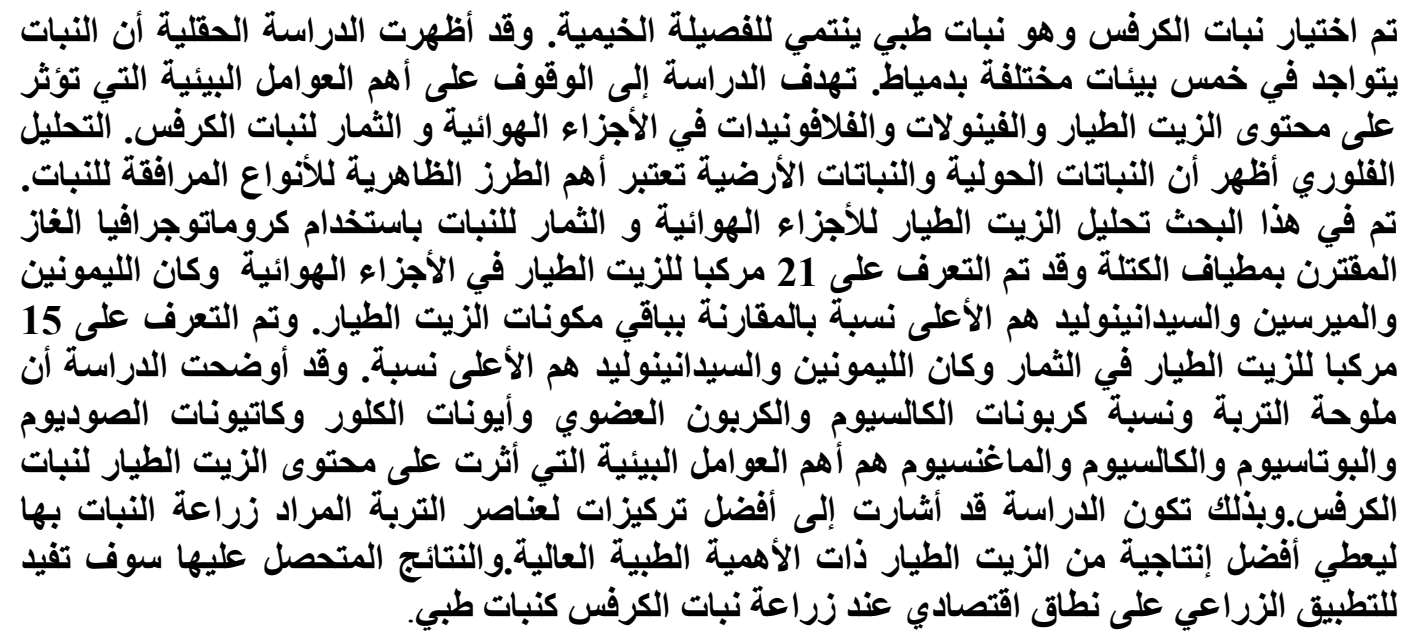

